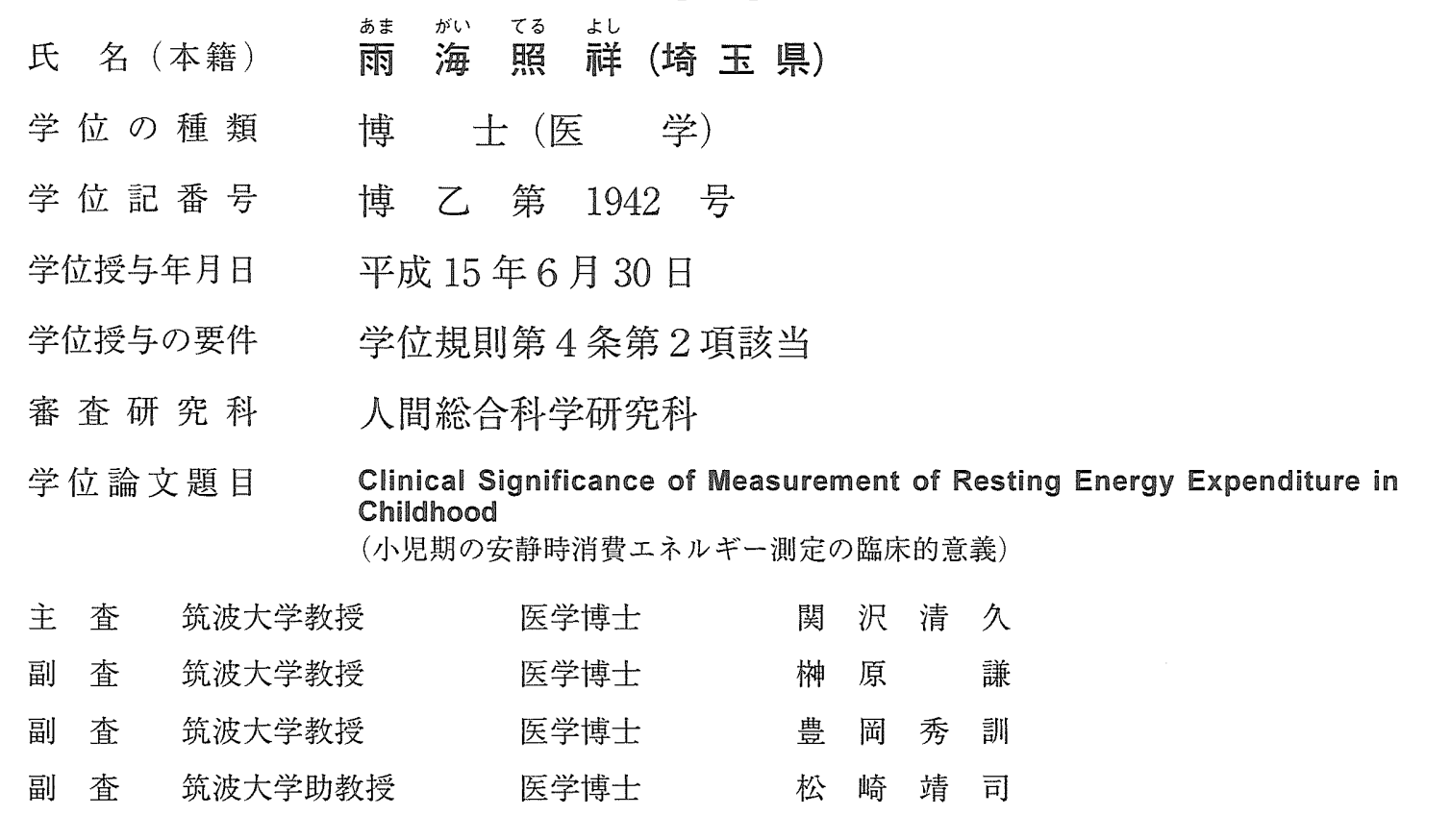

\title{
論文の内容の要 旨
}

（目的）

ひとのエネルギー・バランスを検討する際に，エネルギーのINであるエネルギー摂取量は投与するエ ネルギー量の計測によって知ることができる。一方エネルギーの OUTであるエネルギー消費量 (Energy Expenditure：以下 EE と略す）は実際に対象個々の $\mathrm{EE}$ を計測して得られる。今回, 小児期の異なる $\mathrm{EE}$ 特 性をもつと予想される2つの病態，すなわち本邦に極めて多いとされる胆道閉鎖症（Biliary Atresia：以下 BA）および，逆に白人に多く本邦では極めてまれとされる膵囊胞性線維症（Cystic Fibrosis：以下 CF）が, 健康正常児の $\mathrm{EE}$ 特性と異なるか否か，もし異なるとすれば，どのように異なるのかを検討し，小児期の工 ネルギー特性の意義を明らかにすることを目的とした。

\section{（対象と方法）}

対象

（1）胆道閉鎖症（BA）18 例を $\mathrm{BA}$ 群とした。その内訳は黄疸群（血清ビリルビン值が $1.0 \mathrm{mg} / \mathrm{d} 1$ 以上： $\mathrm{n}=8$ ） と非黄疸群（血清ビリルビン值が $1.0 \mathrm{mg} / \mathrm{dl}$ 未満： $\mathrm{n}=10$ ）を筑波大学附属病院小児外科（以下当科）に扔け る BA 手術リストから無作為に抽出した。年齢の範囲は 8 ケ月から 13 歳である。

（2）当科で治療を受けた脺震胞性線維症（CF）患児 4 例を $\mathrm{CF}$ 群とした。 年齢の範囲は生後 50 日から 12 歳である。

（3）当科に手術目的で入院し，他に合併症を有しないそけいへルニアの小児 90 例を正常健康児とみなし対 照群とした。

方法

研究 1 : 対照群での $\mathrm{EE}$ の測定

そけいヘルニア手術を目的として当科に手術日前日に入院した小児を，入院日の空腹時（22：00〜 $23 ：$ 00 の間の 30 分間）にEEのスポット測定を行った。EEの測定には間接カロリーメトリー法 (Indirect 
Calorimetry：以下 IC と略す) で, Finland, Datex 社製のDeltatracを用いた。また対照群の条件として, 測定当日の最高体温が $37^{\circ} \mathrm{C}$ 未満，他の合併症無し，腫瘍や炎症の病歷，症状，徵候がないことを全て满た すこととした。

研究 $2: \mathrm{BA}$ 群でのエネルギー・バランスの検討

(1) 24 時間記録法による食物摂取調査

3 日間連日で 24 時間毎に，患児の摂取食物を両親に記録してもらう。その結果から，管理栄養士が摂取 エネルギーや栄養素の量の計算を行う。

(2) 身体計測

身体構成成分のうち，皮下脂肪量を算出するため上腕周囲長（Mid-upper arm circumference：以下 MAC と略す)，上腕三頭筋部皮下脂肪厚（Triceps skinfoldthickness：以下TSF と略す）を計測した。MAC, TSF の測定值より上腕筋肉量（Arm Muscle Area：以下 AMA と略す）抽よび上腕断面積（Arm Area：以下AA と略す）を算出し，上腕皮下脂肪量（Arm Fat Area：以下 AFA と略す）を算出した。個々に算出したAFA 值を相互に比較検討する目的で，同性，同年齢での平均值で実測 AFA 值を除した值を求め，測定 AFA を標 準化した。

(3) EE 測定と採尿

$\mathrm{BA}$ 群の $\mathrm{EE}$ 測定法は方法 1 と同様である。また $\mathrm{EE}$ 測定の同日に採尿し，尿素窒素（UN）を測定， $\mathrm{EE} に$ 占める栄養素の酸化画分（Fractional Oxidation Substrate：FOS）を対象毎に算出した。

(4) 血清インターロイキンー6（IL-6）およびレプチン值の計測

IL-6 は侵襲度の指標として radioimmunoassay 法で，またレプチンは体内の脂肪量の指標として enzymelinked immunosorbent assay 法で測定した。

研究 $3: \mathrm{CF}$ 群でのエネルギー特性の検討

(1) $\mathrm{EE}$ 測定と採尿

$\mathrm{BA}$ 群での $\mathrm{EE}$ 測定と同様に扔こなった。

（2）栄養介入と身体測定

予測 $\mathrm{EE}$ を上回る測定 $\mathrm{EE}$ 分のエネルギーを，3ケ月間サプリメントとして補充した。補充するサプリメ ントの組成としては，CFで膵機能障害による脂質の吸収障害を考慮して，一般の長鎖脂肪酸にくらべ吸収 効率の高い中鎖脂肪酸（medium - chain triglyceride：MCT）を選択した。栄養介入 3 ケ月後の時点での身 体測定值である AMA，AFAの測定を行った。

（3）栄養介入による $\mathrm{EE} の$ 変化

栄養介入 3 ケ月前後での $\mathrm{EE}$ を測定し比較検討した。

\section{(結果)}

研究 1 :

対照群での EE は体重と相関性があった。その相関は

$\mathrm{EE}=53 \times($ 体重 $)(\mathrm{kcal} /$ day $)$

の式で近似しえた。

研究 2 :

（1）黄疸群の BA 患児は，過食傾向にあるが，黄疸群での摂取エネルギーの内訳の構成（FOS）は，非黄疸 群のそれと差がなかった。

（2）黄㾝群の $\mathrm{EE}$ は高く，脂肪の酸化が有意に高かった。

（3）黄疸群での血清 IL-6 值が非黄㾝群のそれに比して有意に高かった。 
（4）血清レプチン值は，黄㾝群で低い傾向を認めたが統計学的な有意差はな

かった。

これらの結果より, BA 黄疸群では代謝㐫進, 高サイトカイン血症, 低レプチン血症の傾向があったものの, 統計学的な有意差は認めなかった。

研究 3 :

（1） $\mathrm{CF}$ 患児は，対照群より有意に高い $\mathrm{EE}$ を示した。

（2）栄養介入は EEの減少に働いたが, 統計学的な有意差はなかった。

\section{(考察)}

栄養管理に扔いて，エネルギーを過不足無く投与することは，特にエネルギー摂取の安全域が狭い小児に おいては大切である。しかし小児期のエネルギー・バランスに対して充分な科学的エビデンスをもつ検討が 行われてきたとは言い難い。本研究において間接カロリメトリー法を利用して健康正常児，BA，CFでの消 費エネルギー特性を検討したところ，本邦での発生率が高いBAでは特異なエネルギー・バランス状態にあ ることが示された。このエネルギー特性が黄疸群での栄養障害（protein - energy malnutrition）の原因であ る可能性があると考えられる。一方，本邦での発生症例数が極めて低い CF でも，諸外国例と同様に EE 充 進状態を確認した。また，MCTで補充した栄養介入によりEE元進は軽減できた。

以上から，小児期でのエネルギー・バランスを検討することの臨床的な意義は高いと考えられた。

\section{審 查 の 結 果 の 要 旨}

小児の安静時消費エネルギー（REE）の測定の意義を健康正常児と代謝状態の異なる病態を持つ患児とで 検討を行った論文である。健康正常児 REE の測定より，小坚での安静時消貴エネルギーを算出する式が考 案された。この式は小児の栄養管理を行う上で基準となる意義のある式と考えられる。また，胆道閉鎖症と 膵囊胞性線維症という特殊病態下での代謝特性を検討し，病態に応じた栄養学的介入が極めて重要であるこ とを明らかにした。栄養・エネルギー代謝の側面から小児疾患治療に有用な情報を提供した優れた論文と考 えられる。

よって, 著者は博士（医学）の学位を受けるに十分な資格を有するものと認める。 